\title{
THE INFLUENCE OF COMPETENCE POTENTIAL OF CHANGES IN HIGHER EDUCATION ON THE TRAINING OF SPECIALISTS FOR ENTREPRENEURSHIP
}

\section{WPŁYW POTENCJAŁU KOMPETENCYJNEGO ZMIAN W SZKOLNICTWIE WYŻSZYM NA SZKOLENIE SPECJALISTÓW DLA PRZEDSIĘBIORCZOŚCI}

\author{
Nataliya Vnukova, Professor \\ Simon Kuznets Kharkiv National University of Economics, Department of Banking and Financial Services \\ ave. Nauky, 9a, 61166, Kharkiv, Ukraine \\ ufp2007@meta.ua.ORCID 0000-0002-1354-4838

\section{Svitlana Achkasova, PhD} \\ Simon Kuznets Kharkiv National University of Economics, Department of Banking and Financial Services \\ ave. Nauky, 9a, 61166, Kharkiv, Ukraine \\ svet_achk@meta.ua. ORCID 0000-0001-7233-0189
}

\section{Maryna Us, PhD}

Simon Kuznets Kharkiv National University of Economics, Department of Economics and Marketing ave. Nauky, 9a, 61166, Kharkiv, Ukraine marinaus_@ukr.net.ORCID 0000-0002-4849-0331

\section{Vasyl Pyvovarov, PhD}

Yaroslav Mudryi National Law University, Department of Cultural Studies

Vasiliy st. Pushkinskaya, 77, 61024, Kharkiv, Ukraine

v.pyvovarov@ukr.net•ORCID 0000-0001-9642-3611

DOl: 10.2478/minib-2020-0026

\section{ABSTRACT}

The paper presents the substantiation of the need to reform the higher education system of Ukraine in line with European and international standards and requirements, providing a full transition to competentive approach to learning. The essence and advantages of using competency potential for improvement of the higher education system in Ukraine are determined. A comprehensive marketing research are conducted, using the method of content analysis that helped to reveal the modern competencies needed for students and graduates of financial and legal specialties. In addition, a survey was conducted which showed that there were problems with the level and quality of the formation of professional and key competences. 


\section{ABSTRAKT}

Artykuł prezentuje uzasadnienie potrzeby zreformowania systemu wyższego szkolnictwa Ukrainy w zgodzie z europejskimi i międzynarodowymi standardami i wymogami, co zapewni pełne przejście do kompetencyjnego podejścia do uczenia się. W artykule zostały określone istota i korzyści posługiwania się potencjałem kompetencyjnym dla ulepszenia systemu szkolnictwa wyższego Ukrainy. Zostało przeprowadzone kompleksowe badanie marketingowe z użyciem metody analizy merytorycznej treści, które pomogło w ujawnić nowoczesne kompetencje potrzebne studentom i absolwentom kierunków finansowych i prawniczych. Ponadto przeprowadzono ankietę, która ukazała, że występują problemy z poziomem i jakością kształtowania profesjonalnych i kluczowych kompetencji.

Słowa kluczowe: kompetencje, edukacyjny potencjał kompetencyjny, kompetencje komunikacyjne, kompetencje przedsiębiorcze

JEL: A230, I25, M200

\section{Introduction}

New program for sustainable development, which is reflected in the 17 Global Goals (Transforming our world: The 2030 Agenda for Sustainable Development) was passed by a resolution adopted in New York within the 70th session of the General Assembly of the United Nations in 25.09.2015 No.70/1 "Transforming our world: the 2030 Agenda for Sustainable Development."

The Global Goals program officially came into force on January 1, 2016 and provide for 15-year programs to reach them by 2030. Each country has 
developed specific programs for its sustainable development, and Ukraine is no exception. Within the proposed objectives, it is recognized that poverty eradication is envisaged in conjunction with strategies that should promote economic growth and meet a range of social needs, including education, health, social protection, in particular retirement, and employment opportunities. These challenges are more than ever crucial and decisive for Ukraine.

The modern world is characterized by the existence of a digital economy where growth is the key to human development and its knowledge, skills and competencies are the main resource and foundation for future positive change, so the Bloomberg Innovation Index calculates among others such criteria as the effectiveness of higher education, the percentage of graduates and concentration of researchers in the country (The Bloomberg Innovation Index). In addition, when calculating competitiveness in the Global Competitiveness Report 4.0 (World Economic Forum, 2018), the "Skills" section includes such indicators as "quality of vocational training" and "graduates' skills". All this is a confirmation of the understanding of the importance of the society not only of knowledge, but also its adaptation to contemporary challenges and risks.

In order to be competitive in the new environment, as evidenced by the quantitative studies of European and international organizations (World Economic Forum, 2018), you need to have new competencies, adaptation skills and the ability to constantly learn.

Thus, modern education should be aimed at acquiring the skills to acquire knowledge independently, creative thinking and the ability to apply new knowledge. In addition, the development of communication skills is important. This, in turn, requires a revision of the content, quality, legal and methodological support and approach to the acquisition of all levels of education. This can only be achieved through effective cooperation and cooperation with the state, business, civil society institutions, educational institutions and individuals.

In the context of deepening of the integration of Ukraine with the panEuropean educational space, achieving the goal of modern education requires the transition of higher education to a new concept of training future specialists, taking into account an improved competency approach. In addition, it is advisable to use the competence potential to ensure the 
competitiveness of higher education institutions (HEI) in the European educational space and their trained professionals in the labor market in both national and world markets of different spheres (Vnukova and Achkasova, 2009; Pukala, Lysytsia, Prytychenko, and Gron, 2018). Therefore, there is a need to improve the quality of educational services and the formation of integrated, professional and communicative competencies, especially for graduates of HEI economic and legal specialties and employers. In particular, this can be done through the use of innovative components of training and the introduction of practical financial and legal literacy tools by entrepreneurs themselves. All this determines the relevance of this research and its purpose.

\section{Materials and Methods}

The main purpose of researche is to analyze the current competences emerging in the higher education system and justify the possibility of using the competency potential for changes in the higher education system. Achieving the main goal of the study involves solving a number of problems: 1) analyzing the scientific works of researchers about the nature and benefits of competency approach in higher education; 2) performing content analysis to identify a list of modern competencies of HEI graduates that are necessary for their successful employment and risks that may accompany this process; 3) conducting a survey of HEI graduates of the second (master) and third (education and scientific) level of higher education on awareness of the importance and relevance of their professional competences to the National Qualifications Framework and requirements of today's stakeholders; 4) identifying opportunities to use the advantages of competency perspective and potential for implementation of changes in higher education.

The authors during the years May 2018-December 2019 conducted comprehensive market research on understanding the prospects and potential competency approach in education, establishing a list of specific competencies and specialties of their compliance with the need for change in higher education in Ukraine. For the study collected primary and secondary data on the subject. For primary data used quantitative method 
- survey, including questionnaire which involved tools and procedures. The survey was attended by respondents of the second master's degree and third-level of the higher education students of economic and legal specialties, including students of the 1st year of study for the Master's program "Finance and Credit" in specialty "Finance, banking and insurance" in Simon Kuznets Kharkiv National University of Economics and applicants for educational and scientific level - Doctor of Philosophy in "Law" specialty at Yaroslav Mudryi National Law University.

As part of the study, the authors developed a questionnaire consisting of 3 blocks of questions, a total of 23 closed-ended questions, most of them dichotomous questions or with many options. The sample size was 56 respondents, including 27 men and 29 women. This provided up-to-date primary information on the status, understanding, quality of competencies and the need for changes in the higher education system for graduates of economic, including finance, and legal specialties.

Secondary was data collected as a result of the use of methods of content analysis to identify generalized list of required competencies of HEI graduates and method of analysis of scientific literature - to determine the nature and potential competency approach. Using either of these methods allows to evaluate and justify the use of competency potential opportunities and possibilities for enhanced cooperation between the state, businesses, schools and job seekers at all levels of higher education.

\section{Theory and Measurement}

\section{Theoretical study}

Analysis of many education systems shows that one way to update the content of education and educational technology, improving quality, matching them with modern needs, integration into the world educational space is a focus on curriculum competentive approach and creating effective mechanisms for its implementation. Yet, it can be accepted that approach stands as competentive potential, as noted by Lee and Lee (2016) which combines a set of available opportunities, means in education. 
In order to understand how it is possible to use competency potential, the essence of the most competent approach in education is analyzed.

The authors share Weinert's (2001) view that a clear interpretation of the competence approach and concept of competence is not possible. The scientist argues that there is no uniform application of the concept of competence and the commonly accepted definition of the term. This statement is explained by the fact that there is a variety of experience and scientific positions on the essence of education itself and its purpose in the countries of the world.

According to the definition of the Organization for Economic Co-operation and Development (OECD), competence (competency) is "the ability to successfully respond to needs or successfully complete tasks" (OECD, 2005).

The problem of competence-oriented education in our time, despite the large number of scientific works on this issue, is more urgent than ever; it is developed by well-known international organizations, including UNESCO, UNICEF, UNDP, the Council of Europe, OECD, International Standards Department, etc.

Analysis of works on competency problems allows to distinguish three stages of formation of competence-based approach in education (competence-based education) (Khoruzha, 2007):

- at the first stage (1960-1970) the category "competence" was introduced into the scientific apparatus and the prerequisites for distinguishing the concepts of competence / competency were created;

- the second stage (1970-1990) is characterized by the use of the category of competence in the theory and practice of language teaching (especially non-native), professionalism in management, teaching communication, the content of the concept of "social competence" is developed;

- the third stage (since the 1990s) is characterized by the holistic institutionalization of the approach, its integration into national education systems, which is reflected in the development of UNESCO documents, the implementation of this approach within the Bologna process, and so on.

Since the signing of the Bologna Declaration in 1999, the reorientation of education and the introduction of a competency-oriented approach have 
taken place, the creation of a categorical and conceptual apparatus of the competency approach, which is reflected in the glossary of terms of European education (Tuning Educational Structures in Europe).

Most researchers agree that a competency-based approach to education is designed to "link" education to the manufacturing sector and increase individuals' potential for social, economic, political and cultural transformations that occur in the world and today. This statement emphasizes the role of the individual - the particular individual and the formation of various competences that will allow them to respond appropriately to the challenges and adapt to changes that are happening.

Thus, competency-oriented education is aimed at meeting the personal, social, professional and cultural needs of modern society. Such a claim leads to a transition from a traditional teaching-centered approach to a learningoriented education where the center of the learning process is students and their needs (Figueroa-Rodríguez, Figueroa-Sandoval, and FigueroaRodríguez, 2012).

This opinion is confirmed by research (Pluta-Olearnik, 2019), which emphasizes the importance of involving students in the development of university education, taking into account the expectations (Pukala, Lysytsia, Prytychenko, and Gron, 2018), behavior and characteristics of students in the formation of their competencies.

Improving the quality and level of education requires the higher education system to take comprehensive measures. The starting point for these measures should be the definition of perceptions and expectations (Baruk and Goliszek, 2018). Its should be analyzed not only for all potential participants in the learning process, but also for their various groups, and especially students, as the main consumers of educational services, taking into account, for example, those that differ in demographic criteria. This is important because it may turn out that women and men have different needs for the formation of basic and professional competencies that are necessary to achieve a high level of competitiveness in the labor market and success in entrepreneurship.

A competency approach in higher education involves organizing a learning process that focuses on what students learn or do as a result of learning, not what they should learn. A competency-based approach educates students for the quality of professional work required for the labor 
market, and the criteria and parameters for evaluating educational outcomes are unified and expressed in terms and outcomes that can be interpreted and accounted for in any educational institution of any countries.

On 17 January 2018, the European Parliament and the Council of the European Union approved the Framework Program for updated key competences for lifelong learning (European Commission, 2018). This document sets out a list of the leading competencies that are needed by all individuals to enhance their own development, enhance their employment, social inclusion and active citizenship. Hence, key competencies are a kind of potential for further development of a person in the context of continuous learning. That is, they can be formed and developed in the lifelong learning process. Among competencies different from the previous option proposed in 2006 are: literacy competence; languages competence; personal, social and educational competence; civic competence; entrepreneurship competence.

The formation of these leading competencies is one of the main tasks that can be implemented in the education system at different levels, and a special role in this process is given to higher education. Therefore, the formation of key competences is a priority for change in the higher education system.

\section{Practical study}

The changes that are taking place in the higher education system are related to the challenges of the 21 st century and to the problems of physical survival resulting from increased aggression and reduced social mobility. In Ukraine, these challenges are fully manifested and affect the educational process, which requires decisive action.

Because, in addition to these problems, the complexity and need for change are associated with a number of risks. By origin, as defined by Babina TG. (Babyna, 2016), there are eight groups of probable risks, namely: political-legal, financial-economic, organizational-technical, personnel, management, information-communication, socio-cultural, educational-methodical. 
In 2015, the World Bank Group conducted a study on the level of development and quality of education and the labor market of Ukraine. In the prepared summary "Skills for a modern Ukraine" (Del Carpio, Kupets, Muller, and Olefir, 2015), it was concluded that Ukraine is characterized by a relatively high level of education, a large number of university students and graduates, which in turn contributes to scientific and industrial progress. At the same time, there is a weak economic development and low level of labor productivity in comparison with other countries with the market economy of the respective group, and the standard of living of the average person in 2015 is worse than in 1991 (when the country's independence was declared).

Numerous systemic issues have accumulated throughout the country's education sector throughout the existence of an independent Ukraine (Pukala, Lysytsia, Prytychenko, and Gron, 2018). Among them: the attitude of the governmental structures to the education sector as to the secondary, in comparison with the economy, the "expenditure" rather than investment part of the state budget; decline of material and technical base, aging of teaching staff, insufficient influx of young specialists (Babyna, 2016); low wages, reduced social status of education workers; increasing inequality in access to quality education; non-codification and imperfection of educational legislation; excessive commercialization of educational services; slow and haphazard updating of educational content; decrease in quality of teaching staff and crisis of pedagogical education, lack of professional effective system of monitoring and control of quality of education; decrease in the quality of educational literature and critical shortage of advanced technologies in the educational sector and others (Vnukova and Akchasova, 2009).

One of the main reasons for these unsatisfactory results is the lack or slow pace of reforms, especially in the area of labor market regulation and the activities of educational institutions. The World Bank provided shortcomings and recommendations for necessary changes in education, according to which: workers need a mix of skills (weak practical component of education); education lacks relevance to current standards (requires the acquisition of experience (theory) and increased engagement with employers and entrepreneurs); institutional inefficiency hinders the use and development of skills (the need to change 
the approach to education and education or to improve them); skills mismatch limits the effectiveness of businesses, firms and overall productivity (the need for synergies between education, government, business and education providers to align curricula, programs, and current competencies).

International studies on the quality of higher education show that indicators for Ukraine are rather heterogeneous. In the Table 1 lists Ukraine's ranking on the Global Competitiveness Report 2018 are specified.

Thus, the data in Table 1 indicates the need for changes in the education system. On the one hand, Ukraine ranks 11th to 16 th in the world in terms of enrollment in higher education. In terms of the quality of the education system and management education, Ukraine's place is fluctuating and quite low, indicating the need to reform higher education in economic specialties.

Table 1. Ranking of Ukraine on the "Education" component (compiled by the authors)

\begin{tabular}{l|c|c|c|c}
\hline \multicolumn{1}{c|}{ Indicator } & \multicolumn{3}{c}{ Value index by year } \\
\cline { 2 - 5 } & 2014-2015 & $\mathbf{2 0 1 5 - 2 0 1 6}$ & $\mathbf{2 0 1 6 - 2 0 1 7}$ & $\mathbf{2 0 1 7 - 2 0 1 8}$ \\
\hline The quality of the education system & 65 & 46 & 46 & 49 \\
The quality of the educational system & 72 & 54 & 56 & 56 \\
The quality of the natural and mathematical education etc. & 30 & 38 & 27 & 27 \\
Quality management schools & 88 & 87 & 93 & 88 \\
The share of education & 14 & 14 & 11 & 16 \\
Enrollment in secondary education & 41 & 39 & 53 & 51 \\
Enrollment in HEI & 13 & 14 & 11 & 16 \\
The number of countries participating in the research & 144 & 140 & 138 & 137 \\
\hline
\end{tabular}

Source: World Economic Forum, 2018.

Updating the issue of finding the potential for change in the higher education system is reinforced by the Ratification of the Association Agreement with the EU (September 16, 2014), the adoption in Ukraine of changes to the National Qualifications Framework (On amendments to the 
Cabinet of Ministers of Ukraine of November 23, 2011 No. 1341), the Law of Ukraine "On Education" (On Education: Law of Ukraine dated 05.09.2017 No. 2145-VIII.), A new wording of the Law of Ukraine "On Higher Education" (On Higher Education. Law of Ukraine No. 1556-VII of 1.07.2014 ), The Law of Ukraine "On Amendments to Certain Laws of Ukraine on Improvement of educational activities in higher education "(On amending some laws of Ukraine concerning improvement of educational activities in higher education. The Law of Ukraine number 392 of 18/12/2019-IX).

The updated National Qualifications Framework is based on European and national standards and principles of quality assurance of education, takes into account the requirements of the labor market for the competences of workers and is introduced in order to harmonize legislation in the fields of education and social and labor relations, to promote national and international recognition of qualifications obtained in Ukraine establishing effective interaction between education and the labor market.

Thus, a competency-based approach has already been introduced into the education system through the establishment of industry standards for higher education, which form the prerequisites for greater and more flexible approximation of education outcomes to the needs and requirements of the labor market, to further development of educational technologies and the education system as a whole.

Changes are taking place at the legislative level, but qualitative and effective use of all the established norms requires adaptation and taking advantage of the competent approach.

Provision of quality educational services in the market of educational services (higher education) involves the definition of modern competencies that graduates need for competitiveness in the labor market and further activity, their understanding of the decisions made by the state and business (Lysytsia, Martynenko, Bielikova, Gron, and Us, 2019), and on this basis, proposing specific actions and solutions that would provide the realization of competency potential for qualitative change. In order to obtain the necessary information, a comprehensive marketing study was conducted. 


\section{Results and Discussion}

\section{Results}

In the conditions of intensified competition and the search for ways to improve and development of the higher education system, it is advisable to determine the list of competences of graduates and specialists. To this end, the employers' demand for the required competencies of employees was monitored, which could serve as a source of information on both the existing and potential advantages or disadvantages of organizing the theoretical and practical component of the HEI training process. Taking into account the results of such monitoring will enable to identify those competencies that are in demand in the labor market, to prepare graduates - specialists who are able to make decisions in the conditions of risk and rapid changes in the external environment in the market conditions, which will provide the latter with sustainable competitive advantages.

The research was conducted in two stages. The first stage involved collection of quantitative information for use in the content analysis. The source of data for the analysis were the 6 most popular online job search sites in Ukraine: work.ua, rabota.ua, HeadHunter (hh.ua), jobs.ua, trud.ua and alljob.com.ua. Information was collected with the allocation of resume and vacancy data to positions relevant to the economic and legal specialties and in particular in the field of finance and containing relevant research information. Total data is collected from 9,048 job postings and 10,103 job postings (curriculum vitae) for the period 21.10.19-21.12.19.

The results of the content analysis allowed us to make the following generalizations. Among the most popular (modern) competencies are the following: communicability (corresponds to world trends, and as noted by Pivovarov (2019), is one of the key competences); analytical skills; stress resistance; responsibility; mindfulness and more.

Among the most significant professional competencies were identified: speaking several foreign languages, ability to critique and self-criticize, creativity, use of knowledge in practical situations, skills in organizing and planning events and time management, formulating and solving problems, ability to find processing and analysis of information from different sources, motivated decision making, teamwork, commitment to safety, 
knowledge and understanding of the subject area and understanding of the profession, ability to work internationally th environment, the ability to act, guided by ethical considerations, ability to communicate with people who are not experts in a particular field, the ability to abstract thinking, analysis and synthesis of information; to use of economic and mathematical tools, modern information and communication technologies, software packages of general and special purpose, knowledge of the law, etc.

It should be noted that the large number of vacancies testifies not so much to the wide employment opportunities, but to the candidates' suitability and quality, knowledge and level of competence, or lack of the necessary competence for successful performance of duties in a certain field of activity. In addition, most of the identified competencies cannot be formed in a short period of time, and therefore it is necessary to implement an on-the-job training system, take advantage of dual education (The concept of training specialists in dual education in Ukraine, 2018) or comprehensively meet the needs of the population in lifelong learning.

The first stage of the research made it possible to identify the need for communication and entrepreneurial competences, which are related to the key ones. It is important for employers to stimulate cooperation between higher education and vocational training, then entrepreneurship training is critically valuable.

The second phase of the study involved obtaining primary information by interviewing Masters students and third-level (science) graduates, as the business shows an increasing demand for educational services that provide it with the training of competent specialists to meet the new market requirements. Demand for professionals who have knowledge of financial markets and financial instruments and legal specialists is determined by the pace and level of development of the financial market and financial institutions, legislation. During the period of instability of Ukraine there is a growing demand for highly qualified specialists who possess key professional competencies to work in the relevant financial and legal services markets. Thus, the relevance of research into the problem of professional training of specialists in these specialties increases. The survey was attended by 56 people, the questionnaire itself consisted of 3 blocks of questions: knowledge and understanding of qualification requirements for the specialty; priority of basic and professional competences; a modern specialist and his compliance with the requirements of stakeholders. 
The most important questions and results of the distribution of respondents' answers are presented in Table 2.

According to the results of the Table 2 it can be noted that respondents are not aware of and understand the nature and list of qualifications for a particular level. There, the difference in responses on the need for specialists in certain educational level for orhanzatsiy organization's specialty. This demonstrates the ignorance of trends in the labor market and possible misunderstanding of the nature of the functions performed by specialty. However, the majority of respondents are aware of the lack of preparation and expectation mismatch of employers (32\% of managers consider inadequate, and $43 \%$ - so that only partial compliance).

\section{Table 2. Questions and distribution of respondents' answers by block "Knowledge and understanding of the qualification requirements for the profession"}

\begin{tabular}{|c|c|}
\hline Question & $\begin{array}{l}\text { Distribution } \\
\text { of respondents' answers }\end{array}$ \\
\hline $\begin{array}{l}\text { Are you familiar with the National Qualifications Framework approved by the } \\
\text { Cabinet of Ministers of Ukraine and Ukrainian standards of higher } \\
\text { education in finance (law) }\end{array}$ & $\begin{array}{l}\text { Yes } 39 \% \\
\text { No } 22 \% \\
\text { Partly } 39 \%\end{array}$ \\
\hline $\begin{array}{l}\text { Do you think that these standards of higher education are consistent } \\
\text { with the requirements of the employer or they need to be improved }\end{array}$ & $\begin{array}{c}\text { Yes } 39 \% \\
\text { No } 33 \% \\
\text { Undecided } 28 \%\end{array}$ \\
\hline $\begin{array}{l}\text { Specialists of educational degrees in finance (law), in your opinion, } \\
\text { most needed for organizations operating in the relevant market }\end{array}$ & $\begin{array}{c}\text { Bachelor 15\% } \\
\text { Specialist 38\% } \\
\text { Master 37\% } \\
\text { Doctor of Philosophy 10\% }\end{array}$ \\
\hline $\begin{array}{l}\text { In your opinion, is it sufficient (in line with the expectations of the employer) } \\
\text { to prepare graduates of HEI - specialists in finance (law) who are employed } \\
\text { to work in the institutions of Ukraine in the relevant field of activity }\end{array}$ & $\begin{array}{c}\text { Yes } 25 \% \\
\text { No } 32 \% \\
\text { Partly } 43 \%\end{array}$ \\
\hline
\end{tabular}

Source: authors own elaboration based on research results.

The research asked questions about the priority competences of the National Qualifications Framework, which, according to the respondents, are the most necessary for the chosen profession (no more than 2), the answers were distributed as follows (Table 3). 


\section{Table 3. Distribution of respondents' answers on the priority of basic competences of the National Qualifications Framework for specialty}

\begin{tabular}{l|c|c|c|c|c}
\hline \multirow{2}{*}{ Signs of comparison by gender } & \multicolumn{5}{|c}{ The answers descriptors } \\
& \multicolumn{5}{|c}{ of the National Qualifications Framework (\%) } \\
\cline { 2 - 6 } & Knowledge & Ability & Communications & Autonomy & Responsibility \\
\hline \multirow{2}{*}{ Men } & 48 & 33 & 33 & 18 & 22 \\
Women & 45 & 27 & 59 & 20 & 24 \\
\hline
\end{tabular}

Source: authors own elaboration based on research results.

In general, knowledge, skills and communication are the most important priorities. As can be seen from the Table 3, respondents noted the low level of importance of competence such as autonomy, which indicates a lack of acceptance or unwillingness to perform tasks on their own, to solve problems. This is an indication of the need for competency change.

In addition, the question was asked in the questionnaire, the answers to which were formed on the basis of data obtained in the first stage of the study. The respondent was offered a list of identified contemporary competencies that are important. As a result of the received answers it is determined that the opinion of the majority of respondents $-61 \%$ coincides with the data of the analysis of the requirements of employers regarding the importance and necessity of development of communicative competence. Also, a significant percentage of the answers (about $45 \%$ of the respondents) fell to such professional competencies as: ability to act, creativity. These can be attributed to key competences that, under the EntreComp Framework: Entrepreneurial Competence Framework (Bacigalupo, Kampylis, Punie, and Van den Brande, 2016), directly reflect the definition of entrepreneurship (entrepreneurial competence) as the ability to translate ideas into actions that generate value for others.

Thus, we can state the existence and necessity of using the competent potential of changes in the higher education system at the expense of true formation of communicative and entrepreneurial competence among students and graduates of HEI. This will improve the quality of educational 
services and raise the level of education, especially in circumstances where such an assessment of new changes in higher education legislation will be made in terms of employment of graduates in the specialty.

\section{Discussion}

Positive changes in higher education are possible due to the integration of entrepreneurial competence into the curricula, in parallel with the training of teachers in new (innovative) methods of introduction of educational disciplines, provision of educational literature, the formation of sufficient infrastructure. It is considered appropriate to introduce key entrepreneurial competences into curricula at all levels of education (primary, secondary, vocational, higher and lifelong education), which will promote a nationwide entrepreneurial culture and in the future potentially help to influence economic growth and relieving social tension.

As for communicative competence, it can be developed using innovative teaching tools and techniques. In addition, the implementation of in-depth cooperation and partnership between the state, business, educational institutions and applicants of all levels of higher education will not only increase the level of education, practical training of specialists, but also the overall competence of all parties involved in such cooperation.

Involving small and medium-sized businesses in collaboration with professional and technical institutions and HEIs, as well as career guidance in conjunction with the effective work of advisory services, will be important to meet training needs and to address employment problems.

Potential direction of realization of competence potential can be participation of students, applicants, teachers in the program of academic mobility, as taking of experience and formation of insufficiently developed competences. It is advisable to provide more opportunities for participation in such programs, such as "Erasmus for young entrepreneurs", which may intensify training in the field of internationalization of small and mediumsized enterprises. 


\section{Conclusions}

Currently, state standards of higher education and National Qualifications Framework require new organization technology of educational process and competencies, which are formed during and as a result of training. The achievement of standards and the formation of key competences of the new generation is not possible without the new generation HEI, which should provide the conditions for the development and socialization of young people. Increasing the efficiency of the higher education system is linked to the systematic assessment of its needs for securing and utilizing growth reserves. Particular attention is paid to the nature and properties and benefits of implementing a competency-based approach at all levels of education.

There were no gender differences in the distribution of respondents' answers to the priority of the core competencies of the National Qualifications Framework for the profession, except for the communication component more emphasized by women.

Based on the results of the research, it is proposed to use the competency potential of changes in the higher education system, which will influence: increasing of students' cognitive interest in learning; enhancing their motivation for self-development; increasing the quality of education; development of students' communication and entrepreneurial competences; self- and professional definition of graduates of HEI; adapting graduates to current socio-economic conditions, in particular the labor market; building a model for improving financial literacy and professional competence (as part of key competences of lifelong learning) for specialists, in particular, when developing a risk-oriented system of funded retirement provision, the difference of which can be based on the use of innovative training methods - a three-level training program; raising the technical, methodological and informational culture of teachers; availability of conditions for realization of students' abilities and opportunities; expanding social partnership; meeting the needs of the population in the new quality of educational services; enhancing meaningful engagement between employers, graduates and HEI. Further research should be 
continued in the direction of developing a model of change in the higher education system of Ukraine on the basis of the identified competence potential.

\section{References}

1. About higher education. Law of Ukraine No. 1556-VII of July 1, 2014. Verkhovna Rada of Ukraine No. 37-38, Article 2004. Retrived from http://zakon3.rada.gov.ua/laws/show/1556-18

2. Babyna, T. G. (2016). Risks in the market of educational services. Humanitarny Visnyk Pereyaslav-Hmelnytskogo Derzhavnogo Pedagogichnogo Universytetu imeni Hryhoriya Skovorody, 13, 268-273.

3. Bacigalupo, M., Kampylis, P., Punie, Y., \& Van den Brande, G. (2016). EntreComp: The entrepreneurship competence framework. European Commission Joint Reasearch Centre Science for Policy Report. Publication Office of the European Union. http://doi.org/10.2791/593884.

4. Baruk, A. I. \& Goliszek, A. (2018). Associations with the university as an employer: Opinions of women and men representing young potential employees. Marketing of Scientific and Research Organizations, 2(28), 19-42. http://doi.org/10.14611/ MINIB.28.06.2018.08.

5. Del Carpio, X., Kupets, O., Muller, N., \& Olefir, A. (2015). Skills for a Modern Ukraine: Launch event. World Bank Group. Retrieved from http:/hdl.handle.net/10986/25741

6. European Commission (2018). Annex to the proposal for a council recommendation on key competences for lifelong learning. Retrieved from https://ec.europa.eu/ education/sites/education/files/annex-recommendation-key-competences-lifelonglearning.pdf

7. Figueroa-Rodríguez, B., Figueroa-Sandoval, B., \& Figueroa-Rodríguez, K. A. (2012). Competence training in higher education: the case of the technological master "Prestación De Servicios Profesionales" from The Colegio De Postgraduados (México). Procedia - Social and Behavioral Sciences, 46, 2389-2393. http://doi.org/ 10.1016/j.sbspro.2012.05.490

8. General Assembly of the United Nations (2015). Transforming our world: The 2030 agenda for sustainable development. Resolution 70/1. Retrieved from https:/www.un. org/en/development/desa/population/migration/generalassembly/docs/globalcompact/A_ RES_70_1_E.pdf

9. Khoruzhaya, L. L. (2007). A competency-based approach to education: A retrospective view of the development of an idea. Pedagogical education: theory and practice: collection of scientific papers. Series "Psychology. Pedagogy", (7), 202.

10. Lee, J. W. \& Lee H. (2016). Human capital in the long run. Journal of Development Economics, 122, 147-169. http://doi.org/10.1016/j.jdeveco.2016.05.006 
11. Lysytsia, N., Martynenko, M, Bielikova, N., Gron, O., \& Us, M. (2019). Directions of social partnership of employers and universities in the sphere of economic education in Ukraine. Entrepreneurship and Sustainability, 7(1), 336-352. http://doi.org/10.9770/ jesi.2019.6.4(16)

12. On Amendments to Some Laws of Ukraine on Improving Higher Education Educational Activities. Law of Ukraine No. 392-IX of December 18, 2019. Retrieved from https://zakon.rada.gov.ua/laws/show/392-20/

13. On Amendments to the Resolution of the Cabinet of Ministers of Ukraine of November 23, 2011 No. 1341: Resolution of the Cabinet of Ministers of Ukraine No. 509 of June 12, 2019. Retrieved from https://zakon.rada.gov.ua/laws/show/509-2019-\%D0\%BF/ paran5\#n5

14. On education: Law of Ukraine from 05.09.2017 No 2145-VIII. Retrieved from https://zakon.rada.gov.ua/laws/show/2145-19

15. OECD (2005). The definition and selection of key competencies. Executive Summary. Paris: OECD.

16. Pluta-Olearnik, M. (2019). New generations of students from the perspective of cocreating values at the university. Marketing of Scientific and Research Organizations, 4(34), 1-20. http://doi.org/10.2478/minib-2019-0049

17. Pukala, R., Lysytsia, N. M., Prytychenko, T. I., \& Gron, O. V. (2018). Marketing of economic educational services in Ukraine and Poland. Business Inform, (9), 77-85.

18. Pyvovarov, V. M. (2019). Communicative competence in the moral and legal education of a lawyer's personality: Contradictions of the interaction of morality and law in modern Ukrainian society. Proceedings of the All-Ukrainian Scientific and Practical Conference. Kharkiv, Ukraine: Yaroslav Mydryi National Law University.

19. The Bloomberg Innovation Index (2015). Retrieved from https:/www.bloomberg.com/ graphics/2015-innovative-countries/

20. The concept of training specialists in dual education in Ukraine. (2018). Retrieved from http://www.uam.in.ua/upload/medialibrary/3fb/3fb2c5c519f60251581d83fc2c13 9b61.pdf

21. Tuning Educational Structures in Europe. Retrieved from http://www.owwz.de/ glossar.html?\&L=2\&tx_sfbolognaglossar_pi1[s]=RU\&tx\%20\%20_sfbolognaglossar_pi1[ uid] $=52$

22. Vnukova, N. M. \& Achkasova, S. A. (2009). Competent approach in providing quality educational services in the preparation of students of educational and qualification level "Master". New Collegium, (6), 26-32.

23. Weinert, F. E. (2001). Concept of competence: A conceptual clarification. In D. S. Rychen \& L. H. Salganik (Eds), A Contribution of the OECD Program Definition and Selection of Competencies: Theoretical and Conceptual Foundations Definition and Selection of Key Competencies. Gottingen: Hogrefe \& Huber. http://doi.org/10.1.1.111.1152 $\&$ rep $=$ rep $1 \&$ type $=$ pdf

24. World Economic Forum (2018). The global competitiveness report 2018. Retrieved from http://reports.weforum.org/global-competitiveness-report-2018/ 
Nataliya Vnukova, Doctor of Economics, Professor, Simon Kuznets Kharkiv National University of Economics, Ukraine - Professor of the Department of Banking and Financial Services, Honored Economist of Ukraine. Her research interests include problems of competence approach to training, innovative approaches to entrepreneurship, financial monitoring, marketing of financial services.

Svitlana Achkasova, PhD, Simon Kuznets Kharkiv National University of Economics, Ukraine Candidate of Economics, Associate Professor, Associate Professor of the Department of Banking and Financial Services. Her research interests include problems of competence approach, quality assurance of higher education.

Maryna Us, PhD, Simon Kuznets Kharkiv National University of Economics, Ukraine - Candidate of Economics, Associate Professor of the Department of Economics and Marketing. Her research interests include problems of educational services marketing, social entrepreneurship and enterprise partnerships, international marketing.

Vasiliy Pyvovarov, PhD, Yaroslav Mudryi National Law University, Ukraine - Candidate of Philology, Associate Professor of the Department of Cultural Studies. His research interests include problems of training of specialists according to the competence approach, language of law, modern issues of linguistics, development of universities. 